\title{
IbM PENGEMBANGAN KEPROFESIAN BERKELANJUTAN (PKB) GURU-GURU MIM WILAYAH NGAWEN DAN KLATEN UTARA BERBASIS KURIKULUM 2013
}

\author{
Laili Etika Rahmawati, Joko Santosa, dan Muhroji \\ Fakultas Keguruan dan Ilmu Pendidikan \\ Universitas Muhammadiyah Surakarta \\ Jln. A. Yani, Tromol Pos 1, Pabelan, Surakarta 57102 \\ Email: Laili.Rahmawati@ums.ac.id
}

\begin{abstract}
The society service has aimed at accompanying the teachers on understanding and conducting the program of sustainable professionalism development (PKB) based on curriculum 2013. When the society service program has finished conducted, it is expected to acquire the four goals as follow: (1) the emergence of a professional teacher group and acquire the teaching competence by implementing the active learning strategy with scientific approach based on curriculum 2013; (2) the learning devices based on curriculum 2013; (3) the research proposal is classroom action research; and (4) the scientific publication article. The method applied in the society service program was conducted with the same model as the PLPG program conducted but the program implementation was simpler or could be called as mini PLPG. The program activity was beginned by deepening of material activity which related to the concept of PKB and the concept of curriculum 2013. The concept of PKB emphasized on three points that should be developed by the teachers, they were the self development, scientific publication, and innovative work. The concept of curriculum 2013 has priority on the changing understanding of the paradigm and the basic concept of curriculum structure, the prominent were about the core and the basic competences. After the deepening materials which conducted in the first phase has finished, the activity then continued by the workshop of the learning devices which emphasized on the concept of scientific approach, the active learning, and the authentic assessment which followed by peer teaching activity. The worshop activity of learning devices was conducted by facilitating the teachers in arranging the learning scenario based on the materials determined. The peer teaching activity was conducted by divide the participants into some groups to conduct the teaching practice by turns and apply the scientific approach. The third phase was the arranging the academic writing, and it has the priority on the arranging of classroom action research (PTK). The teachers were assigned to propose the classroom action research title based on the problem emerged on their classroom. After the teachers have determined the title, the society service team divisible the job to accompany the teachers in arranging the classroom action research. The strategy used in conducting the third phase, the society servicec team acted as the consultant. By the strategies applied, it is expected that the teachers would be more directed in writing and arranging the classroom action research in order to produce the quality academic writing.
\end{abstract}

Kata kunci: profesi, guru, berkelanjutan, kurikulum 2013 


\section{PENDAHULUAN}

"Guru yang baik terwujud dari hati" (Barbara Dorff, guru sekolah lanjutan teladan dari Texas) dan "Hal yang paling indah tentang mengajar adalah bahwa semakin banyak kita memberi, maka semakin banyak pula yang akan kita peroleh kembali." (Richard Sprecher, guru teladan dari Montgomery Country, Maryland) (Fakhrudin, 2009:98).

Menyambut diberlakukannya Permenpan dan RB No. 16 tahun 2009 per 1 Januari 2013, maka guru perlu mengetahui dan mempersiapkan diri menjadi guru profesional. Guru profesional memerlukan pengembangan keprofesian berkelanjutan (PKB). Guru harus terus mengembangkan keprofesiaannya melalui berbagai pelatihan, seminar, workshop, dan lokakarya yang berkaitan dengan kompetensi pedagogik, profesional, kepribadian, dan sosial. PKB dilaksanakan dalam upaya mewujudkan guru yang profesional, bermartabat, dan sejahtera; sehingga guru dapat berpartisipasi aktif untuk membentuk insan Indonesia yang bertakwa kepada Tuhan YME, unggul dalam ilmu pengetahuan dan teknologi, memiliki jiwa estetis, etis, berbudi pekerti luhur, dan berkepribadian. Hal ini menjadi dasar utama pengembangan keprofesian seorang guru profesional (Rohmadi, 2012:37)

PKB adalah pengembangan kompetensi guru yang dilaksanakan sesuai dengan kebutuhan, bertahap, dan berkelanjutan untuk meningkatkan profesionalitasnya (Permenpan, Pasal 1 butir 5). PKB bagi guru mencakup tiga kegiatan: (1) pengembangan diri; (2) publikasi ilmiah; dan (3) karya inovatif. Tujuan umum PKB yaitu untuk meningkatkan kualitas layanan pendidikan di sekolah/ madrasah dalam rangka meningkatkan mutu pendidikan.

Hidayatullah (2010:18) berpendapat bahwa guru yang memiliki makna "digugu dan ditiru" (dipercaya dan dicontoh) secara tidak langsung juga memberikan pendidikan karakter kepada peserta didiknya. Oleh karena itu, profil dan penampilan guru seharusnya memiliki sifat-sifat yang dapat membawa peserta didiknya ke arah pembentukan karakter yang kuat.

Data tahun 2012/2013 Majlis Dikdasmen PDM Klaten khususnya tentang Madrasah Ibtidaiyah dan Sekolah Dasar Muhammadiyah menunjukkan terdapat 57 MIM dan 12 SDM. Berkaitan dengan status guru yang mengajar di sekolah-sekolah tersebut, mayoritas guru berstatus sebagai guru tidak tetap (GTT). Jika dijabarkan jumlah guru DPK dari kemenag adalah 125 orang, guru DPK kabupaten 1 orang, guru tetap 30 orang, dan guru tidak tetap 626 orang. Jumlah guru tidak tetap yang mencapai $80 \%$ hendaknya diimbangi dengan peningkatan profesionalisme guru agar mereka mampu mengemban amanah sebagai pendidik siswa yang jumlahnya 10.913 orang.

Upaya untuk mengembangkan profesionalisme guru telah diusahakan oleh tim pengusul pada Juli 2013 dengan mengadakan kegiatan pengabdian masyarakat berkaitan dengan pengembangan keprofesian berkelanjutan (PKB) yang difokuskan pada publikasi ilmiah. Dalam kegiatan tersebut diketahui bahwa guru yang menjadi peserta (48 orang) belum satupun yang pernah mencoba menulis publikasi ilmiah. Guru masih takut mencoba, takut salah, dan takut pekerjaannya sia-sia karena bagi mereka menulis merupakan kegiatan yang selama ini dipandang menakutkan dan sulit sehingga membayangkan untuk menulis saja sudah takut.

Jika dikaitkan dengan program PKB guru harus melakukan publikasi ilmiah dan menciptakan karya inovatif, maka guru perlu didampingi agar mampu menciptakan karyakarya tersebut. Guru membutuhkan pendamping dalam menyusun karya tulis ilmiah. Untuk itu tim pengusul pengabdian masyarakat merasa mempunyai tanggung 
jawab untuk mendampingi guru-guru tersebut sehingga harapan untuk menjadi guru profesional dapat segera terwujud.

Februari 2014, tim pengusul bermaksud untuk menindaklanjuti kegiatan tersebut, akan tetapi isu tentang Kurikulum 2013 sedang hangat dibicarakan sehingga kegiatan yang semula direncanakan untuk menindaklanjuti kegiatan sebelumnya berputar haluan untuk membekali guru unttuk memahami paradigma Kurikulum 2013. Berdasarkan kegiatan tersebut di lapangan tim pengusul menemukan bahwa pemahaman guru terhadap Kurikulum 2013 masih rendah. Hal tersebut ditunjukkan dengan banyaknya guru yang belum mengenal buku siswa dan buku guru, serta pendekatan pembelajaran scientific yang mengakibatkan guru merasa kesulitan dalam mengembangkan perangkat pembelajaran, khususnya RPP.

Menurut keterangan pimpinan Majlis Dikdasmen Cabang Ngawen Klaten dan Klaten Utara, latar belakang keilmuan, pengalaman, dan kompetensi yang dimiliki oleh guru-guru MIM perlu dikembangkan. Dalam hal ini terutama yang berkaitan dengan kompetensi paedagogik dan profesionalnya. Mencermati kondisi yang demikian, guru-guru MIM dipandang perlu untuk mendapatkan pencerahan melalui kegiatan pengabdian kepada masyarakat dengan judul "IbM Pengembangan Keprofesian Berkelanjutan (PKB) GuruGuru MIM Wilayah Ngawen dan Klaten Utara Berbasis Kurikulum 2013"

Berdasarkan analisis situasi di atas dan dari penjelasan mitra serta studi awal yang dilakukan tim pengabdian kepada masyarakat FKIP UMS dapat diidentifikasi permasalahan yang dihadapi mitra (dalam hal ini para guru MIM Majlis Dikdasmen Cabang Ngawen dan Klaten Utara Klaten) sebagai berikut.
1. Kurang dipahaminya prosedur pengembangan keprofesian berkelanjutan (PKB).

2. Kurangnya pemahaman tentang kurikulum 2013.

3. Belum berkembangnya kemampuan menulis ilmiah guru dalam bentuk penelitian tindakan kelas (PTK).

4. Konsep pembelajaran dan penilaian berdasarkan Kurikulum 2013 belum dipahami dengan baik karena selama ini baru sebatas mendengarkan (belum mempraktikkan).

Guru diharapkan profesional dalam bidangnya sesuai dengan kompetensi yang dimiliki. Hal ini dapat diukur dengan berbagai perangkat penilaian kinerja yang dipersiapkan. Namun demikian seorang guru yang belum memiliki kinerja memuaskan harus dilakukan pembinaan pengembangan profesi secara berkelanjutan. Hal inilah yang harus dilakukan oleh kepala sekolah dan jajaran terkait.

Seorang guru dapat mengimplementasikan empat kompetensi utama dalam berbagai ranah pembelajaran. Hal ini bergantung pada kemauan dan niat tulus seorang guru untuk mengembangkan profesinya secara berkelanjutan. Oleh karena itu, motivasi untuk belajar dan terus mengembangkan diri harus dilakukan terus menerus.

Rohmadi (2012:77-79) menyatakan bahwa PKB bagi guru memiliki tujuan umum untuk meningkatkan kualitas layanan pendidikan di sekolah/ madrasah dalam rangka meningkatkan mutu pendidikan. Sementara itu, tujuan khusus PKB adalah sebagai berikut.

1. Memfasilitasi guru untuk mencapai standar kompetensi profesi yang telah ditetapkan.

2. Memfasilitasi guru untuk memutakhirkan kompetensi yang mereka miliki sekarang dengan apa yang menjadi tuntutan ke depan berkaitan dengan profesinya. 
3. Memotivasi guru-guru untuk tetap memiliki komitmen melaksanakan tugas pokok dan fungsinya sebagai tenaga profesional.

4. Mengangkat citra, harkat, martabat profesi guru, rasa hormat dan kebanggaan kepada penyandang profesi guru.

Mengacu pada tujuan tersebut di atas, diharapkan PKB dapat menjadi salah satu upaya pengembangan profesi bagi guru secara berkelanjutan. Secara jelas dapat dilihat pada lampiran Permenpan No 16 tahun 2009 .

Setelah kegiatan pengabdian masyarakat ini dilaksanakan, luaran yang ditargetkan meliputi empat hal.

1. Lahirnya sekelompok guru yang profesional dan memiliki kompetensi mengajar dengan menerapkan strategi pembelajaran aktif dengan pendekatan scientific yang sesuai dengan kurikulum 2013.

2. Perangkat pembelajaran berdasarkan Kurikulum 2013.

3. Proposal penelitian tindakan kelas.

4. Artikel publikasi ilmiah.

\section{METODE PELAKSANAAN}

Melihat berbagai permasalahan di atas, maka ditawarkan solusi dengan melaksanakan kegiatan dengan model seperti pelaksanaan program PLPG akan tetapi dibuat lebih sederhana atau bisa juga disebut dengan istilah mini PLPG.

Kegiatan ini diawali dengan kegiatan pendalaman materi berkaitan dengan konsep PKB dan konsep Kurikulum 2013. Konsep PKB ditekankan pada tiga hal yang harus dikembangkan guru yaitu pengembangan diri, publikasi ilmiah, dan karya inovatif. Konsep Kurikulum 2013 diprioritaskan pada pemahaman perubahan paradigma dan konsep dasar struktur kurikulum, utamanya tentang kompetensi inti dan kompetensi dasar.
Setelah pendalaman materi yang dilaksanakan pada tahap pertama selesai, kegiatan dilanjutkan dengan workshop perangkat pembelajaran yang ditekankan pada konsep pendekatan scientific, pembelajaran aktif, dan penilaian autentik yang dilanjutkan dengan peer teaching. Kegiatan workshop perangkat pembelajaran dilakukan dengan cara memfasilitasi guru dalam menyusun skenario pembelajaran berdasarkan materi yang telah ditentukan. Kegiatan peer teaching dilakukan dengan cara membagi peserta menjadi beberapa kelompok untuk praktik mengajar secara bergantian dengan menerapkan pendekatan scientific.

Tahap yang ketiga yaitu tahap penyusunan karya tulis ilmiah, dalam hal ini diprioritaskan dalam penyusunan penelitian tindakan kelas (PTK). Guru diberi tugas untuk mengajukan judul PTK sesuai dengan permasalahan yang dihadapi di kelasnya masing-masing. Setelah guru menentukan judul, tim pengabdian masyarakat berbagi tugas untuk mendampingi guru-guru dalam menyusun PTK. Strategi yang digunakan dalam pelaksanaan tahap ketiga, tim pengabdian masyarakat berperan sebagai konsultan. Dengan strategi semacam ini diharapkan guru lebih terarah dalam menulis PTK sehingga hasil karya ilmiah dapat terwujud.

\section{HASIL DAN PEMBAHASAN}

\section{Pelaksanaan IbM Tahap I tentang Pengembangan Keprofesian Berkelanjutan}

Berdasarkan hasil pelaksanaan kegiatan IbM Pengembangan Keprofesian Berkelanjutan (PKB) Guru-Guru MIM Wilayah Ngawen dan Klaten Utara Berbasis Kurikulum 2013 khususnya tentang Pengembangan Keprofesian Berkelanjutan (PKB) berbasis publikasi ilmiah dapat disampaikan evaluasi sebagai berikut. 
Secara umum kegiatan IbM ini dapat dilaksanakan dengan baik dan dikatakan berhasil dalam arti target yang diharapkan dapat tercapai. Hal ini dapat dilihat dari pelaksanaan pada tahap demi tahap.

a. Dalam Mengikuti Penyuluhan dan Pelatihan

Guru-guru MIM (peserta workshop) terlihat antusias dalam mengikuti sosialisasi, penyuluhan, dan pelatihan sebagai upaya pendalaman materi mengenai beberapa hal yang berkaitan dengan $\mathrm{PKB}$, profesionalisme guru, dan publikasi ilmiah. Kegiatan ini berlangsung komunikatif pada saat sesi tanya jawab berlangsung.

b. Dalam Mengikuti Workshop dan Pendampingan

Para peserta sangat antusias ketika tim IbM menyampaikan bahwa menulis karya ilmiah itu penting. Kegiatan ini diawali dengan proses penggalian ide dengan memberikan beberapa contoh artikel publikasi ilmiah populer yang ditulis oleh fasilitator dan telah diterbitkan di media masa. Guru sangat termotivasi ketika tulisan dapat ditelurkan dari ide-ide yang sangat sederhana. Kegiatan selanjutnya adalah peserta mencoba untuk menuliskan ideidenya ke dalam bentuk artikel publikasi ilmiah populer.

c. Dalam Mengikuti Kegiatan Peer Correction

Setelah ide dituangkan ke dalam bentuk tulisan. Setiap peserta menukarkan hasil tulisannya untuk dikoreksi oleh rekan sejawat. Mayoritas peserta menyatakan bahwa teknik menulis yang berkaitan dengan ejaan yang disempurnakan selalu menghantui ketika mereka menulis. Kegiatan peer correction membantu guru untuk menghilangkan rasa takut menulis karena hal-hal yang berkaitan dengan teknik penulisan, khususnya ejaan merupakan pekerjaan editor. Yang terpenting adalah guru berani menuangkan idenya ke dalam bentuk tulisan. Hal ini merupakan gerbang utama untuk menjadi penulis sejati. Penulis yang selalu mencoba dan tidak pantang menyerah.

Keberhasilan pelaksanaan tahap I ini dapat dilihat dari beberapa indikator sesuai dengan rancangan yang ditetapkan sejak awal. Indikator keberhasilan itu adalah sebagai berikut.

a. Pemahaman tentang konsep PKB, guru profesional, dan artikel publikasi ilmiah Peserta memahami konsep PKB sebagai landasan untuk menjadi guru yang profesional. Meskipun mayoritas guru MIM bukan PNS, namun mereka memahami benar bahwa PKB tidak hanya kewajiban guru PNS, tetapi semua guru yang ingin menjadi guru profesional. Profesionalitas guru yang dikembangkan melalui PKB, yaitu pengembangan diri, publikasi ilmiah, dan karya inovatif. Menjadi peserta workshop dalam kegiatan IbM merupakan usaha guru dalam rangka pengembangan diri. Publikasi ilmiah merupakan salah satu komponen PKB yang disyaratkan untuk kenaikan pangkat dari IVa ke IVb. satu karya ilmiah yang dipublikasikan mendapatkan skor 2. Namun, bukan berarti karya ilmiah hanya boleh dilakukan oleh guru yang kepangkatannya IVa yang ingin naik ke IVb karena guru yang kepangkatannya IIIa pun bisa mengajukan kenaikan pangkat dengan publikasi ilmiah. Oleh karena itu, mulai menulis ilmiah bagi guru yang belum berpangkat sekalipun merupakan langkah awal untuk mengembangkan profesionalitasnya sehingga jiwa sewaktu-waktu guru harus mengajukan kenaikan pangkat, syarat publikasi ilmiah tidak menjadi beban berat. 
b. Kemampuan Menuangkan Ide dan Motivasi Menulis Meningkat

Motivasi peserta untuk menulis meningkat. Hal ini dapat dilihat dari antusiasme peserta dalam menggali ide dan menuangkan gagasannya dalam bentuk tertulis. Menulis yang awalnya dianggap sebagai keterampilan yang sangat sulit dan tidak dibutuhkan sekarang dianggap sebagai keterampilan yang wajib dimiliki guru untuk mengembangkan profesionalitasnya. Kemampuan menulis dapat dikembangkan dari ide-ide yang sederhana tetapi bermanfaat. Penggunaan ejaan yang selama ini dianggap sebagai penyebab guru enggan mencoba menulis dengan kegiatan ini mereka menyadari bahwa kunci keberhasilan menulis adalah ketika seseorang mau mencoba menuangkan ide ke dalam bentuk tulisan.

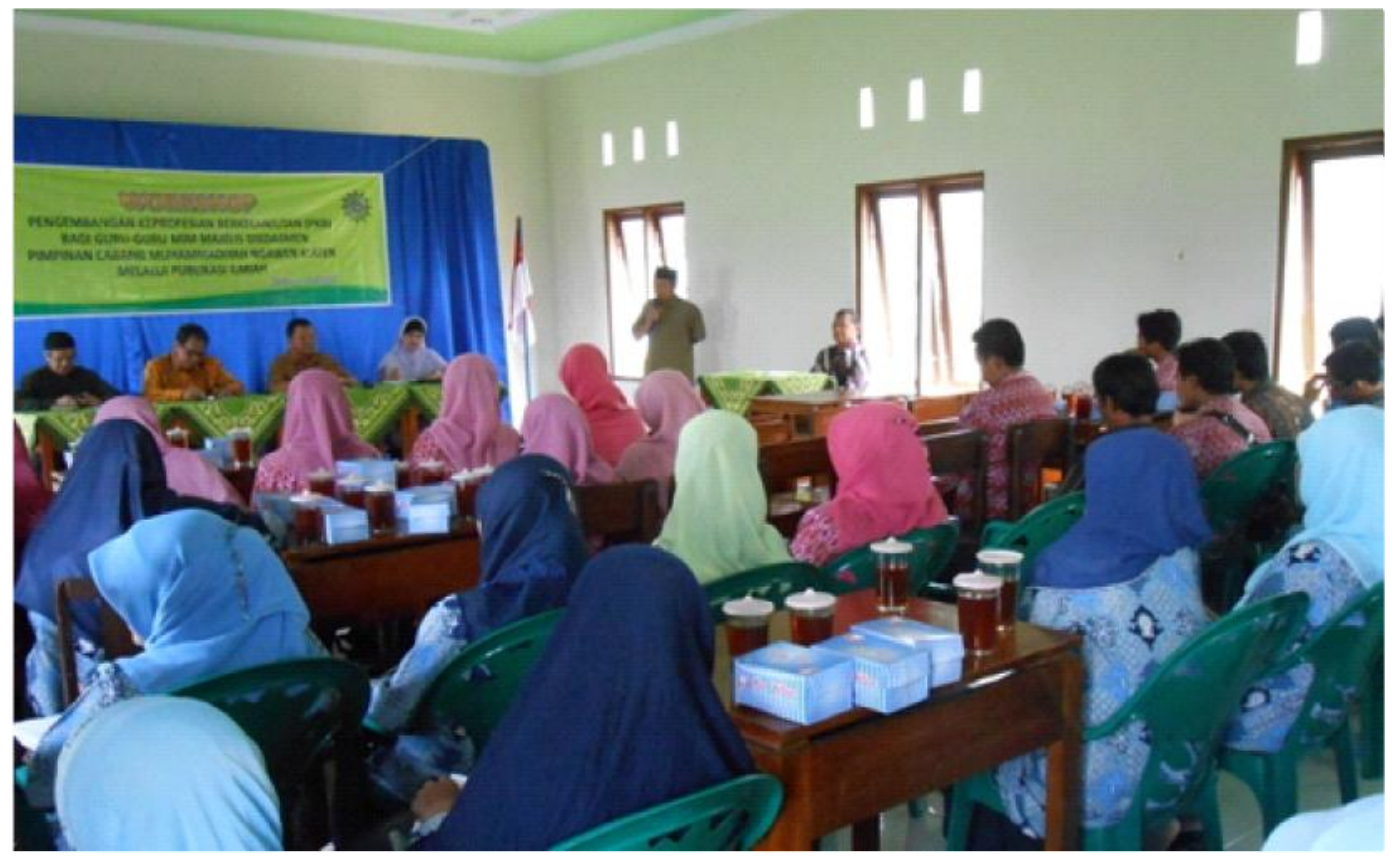

Gambar 1. Pelatihan Kegiatan

2. Pelaksanaan IbM Tahap II tentang Pembelajaran Aktif dengan Pendekatan Scientific Berdasarkan Kurikulum 2013

Berdasarkan hasil pelaksanaan kegiatan pengabdian masyarakat IbM tentang Pembelajaran Aktif dengan Pendekatan Scientific Berdasarkan Kurikulum 2013 disampaikan evaluasi sebagai berikut.

Secara umum kegiatan IbM ini dapat dilaksanakan dengan baik dan dikatakan berhasil dalam arti target yang diharapkan dapat tercapai. Hal ini dapat dilihat dari pelaksanaan pada tahap demi tahap. a. Dalam Mengikuti Pendalaman Materi

Peserta workshop sangat responsif ketika tim pengabdian masyarakat menyampaikan tentang perubahan paradigma pembelajaran dalam kurikulum 2013. Guru sangat semangat ketika diajak bernyanyi oleh pembicara yang isinya berkaitan dengan semangat guru untuk senantiasa belajar untuk dapat menyampaikan hasil belajarnya kepada siswa-siswanya di sekolah dan untuk selalu meningkatkan profesionalisme guru. 
b. Dalam Mengikuti Workshop dan Pelatihan

Kedekatan antara instruktur dengan peserta mengakibatkan workshop dan pelatihan berjalan dengan sangat lancar. Peserta tidak segan-segan bertanya ketika mereka merasa tidak jelas dan peserta berhasil menyusun RPP sesuai dengan tugas yang diberikan oleh instruktur.

c. Dalam Mengikuti Kegiatan Peer Teaching

Peer teaching dipraktikan perwakilan guru di kelas. Kegiatan ini dilaksanakan dengan cara mempraktikkan kegiatan pembelajaran sesuai dengan RPP yang telah disusun pada tahap sebelumnya.

Keberhasilan program IbM ini dapat dilihat dari beberapa indikator sesuai dengan rancangan yang ditetapkan sejak awal. Indikator keberhasilan itu adalah sebagai berikut.

a. Semua guru berhasil menyusun RPP berdasarkan kurikulum 2013

Semua peserta workshop berhasil menyusun RPP sesuai dengan format Kurikulum 2013. Sekalipun ada beberapa kendala yang dihadapi dalam proses penyusunan RPP tersebut, namun mereka tetap konsisten untuk menyelesaikan semua tugas yang diberikan. Adapun kendala yang dihadapi dalam pelaksanaan kegiatan ini adalah: (1) tidak ada guru yang memiliki dokumen tentang buku guru dan buku siswa berdasarkan kurikulum 2013; (2) listrik yang berdaya rendah mengakibatkan pemadaman yang mengakibatkan buku guru dan buku siswa yang berbentuk softfile tidak dapat ditayangkan. Masalah inilah yang menyebabkan instruktur harus mendeskripsikan format RPP di papan tulis dan mendiktekan unsur-unsur yang harus ada dalam RPP tersebut.

b. Motivasi guru untuk praktik di depan kelas

Setelah berhasil menyusun RPP guru diberi tugas untuk mempraktikkannya di depan temanteman yang lain. Ada beberapa guru yang semangat untuk maju tanpa ditunjuk. Setelah guru praktik, temanteman yang lain memberikan komentar. Dari komentar yang disampaikan temantemannya diketahui bahwa guru harus mampu mengaplikasikan secara nyata RPP yang telah disusun. Langkahlangkah yang sudah ditentukan harus disesuaikan dengan praktik yang dilakukan sehingga terjadi kesesuaian antara RPP dengan praktik.

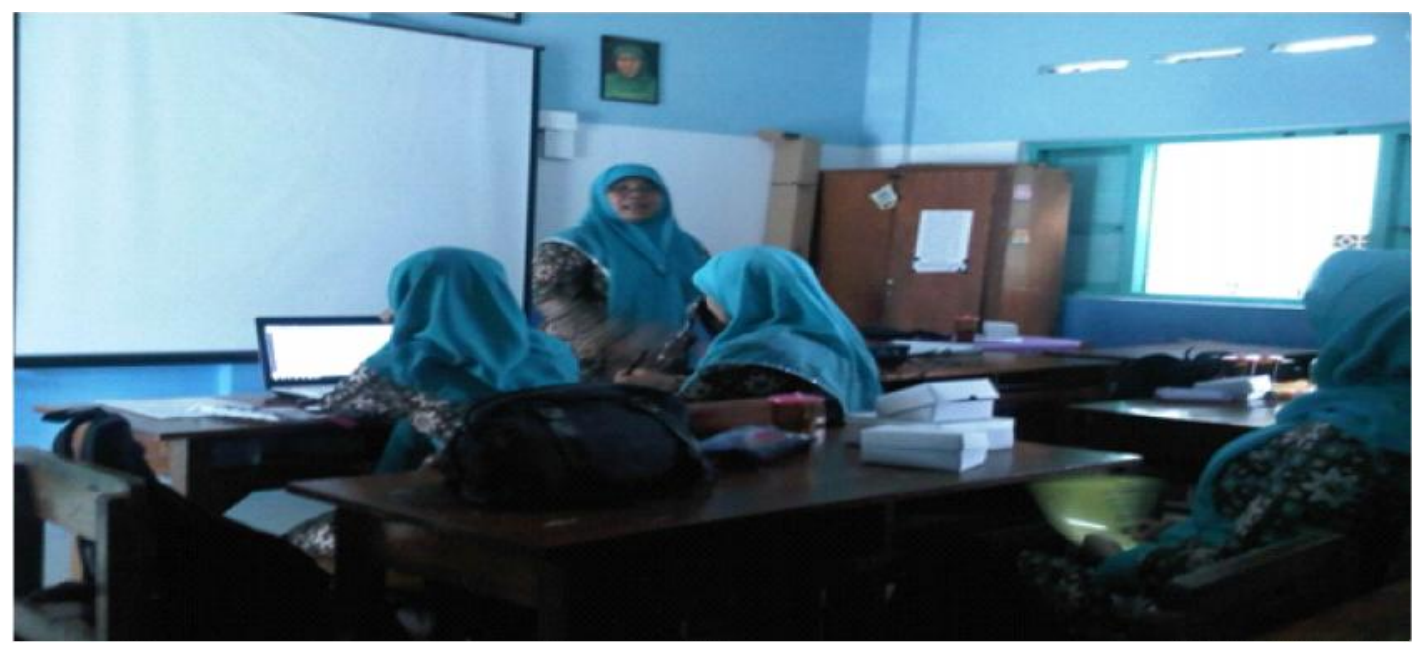

Gambar 2. Penyusunan RPP 


\section{Pelaksanaan IbM Tahap III tentang Penelitian Tindakan Kelas}

Berbeda dengan tahap-tahap sebelumnya, pelaksanaan pengabdian masyarakat IbM tahap III ini tidak diawali dengan presentasi tentang materi PTK, tetapi langsung pada penggalian ide dengan tahap-tahap berikut ini.

a. Peserta dimita untuk berkelompok sesuai dengan tingkatan mengajar di kelas atau bidang ilmu yang relevan. Setiap kelompok maksimal terdiri atas 4 orang. Setiap kelompok diberi tugas untuk menggali ide tentang permasalahan yang dihadapi di kelasnya.

b. Hasil penggalian ide kemudian ditulis pada kertas yang telah disediakan oleh tim pengabdian masyarakat IbM.

c. Masalah yang ditemukan kemudian diidentifikasi dan dirumuskan sebuah judul yang cocok untuk penelitian tindakan kelas.

d. Setelah itu setiap kelompok mempresentasikan hasil identifikasi masalah yang telah ditentukan

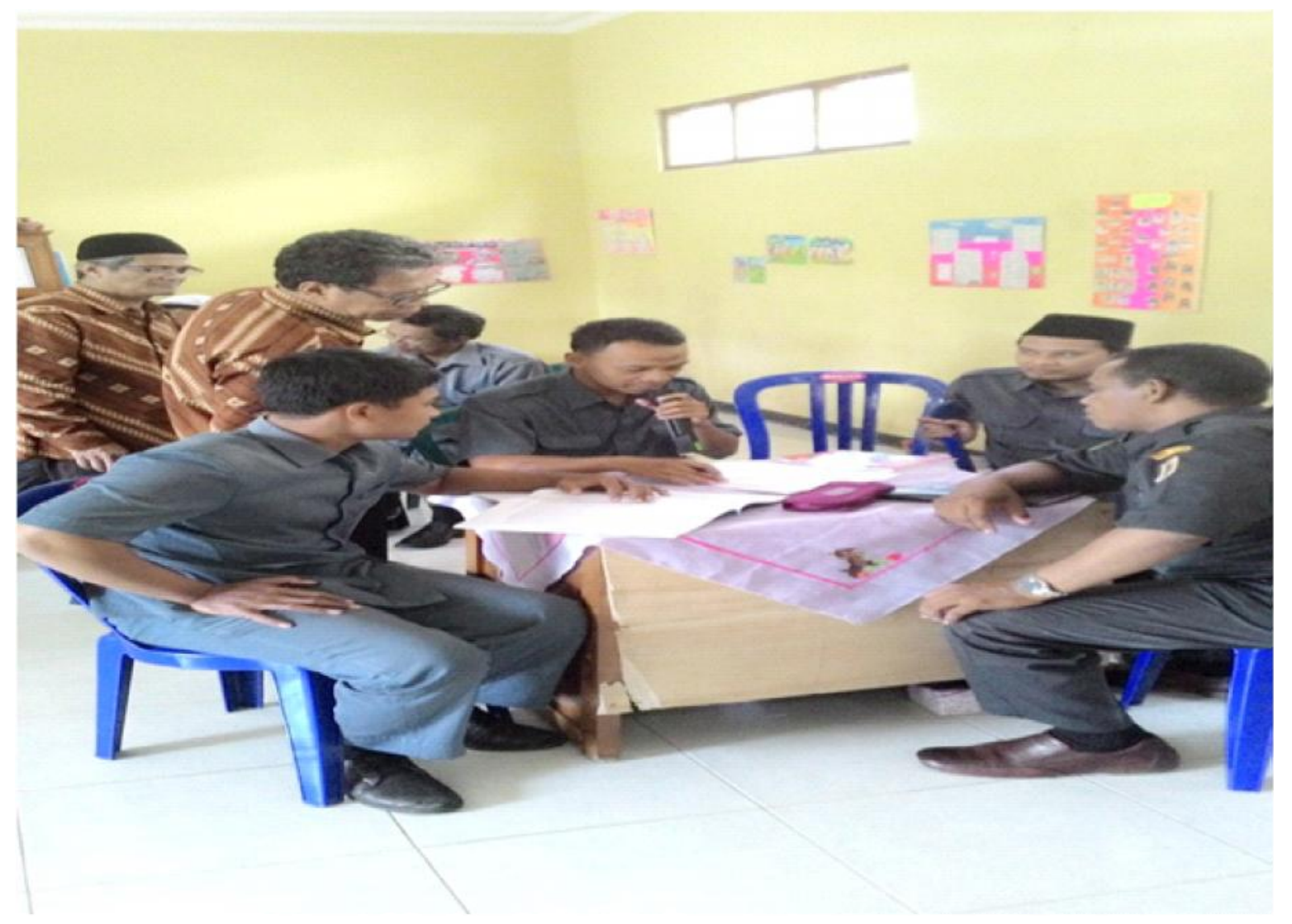

Gambar 3. Penggalian Ide 


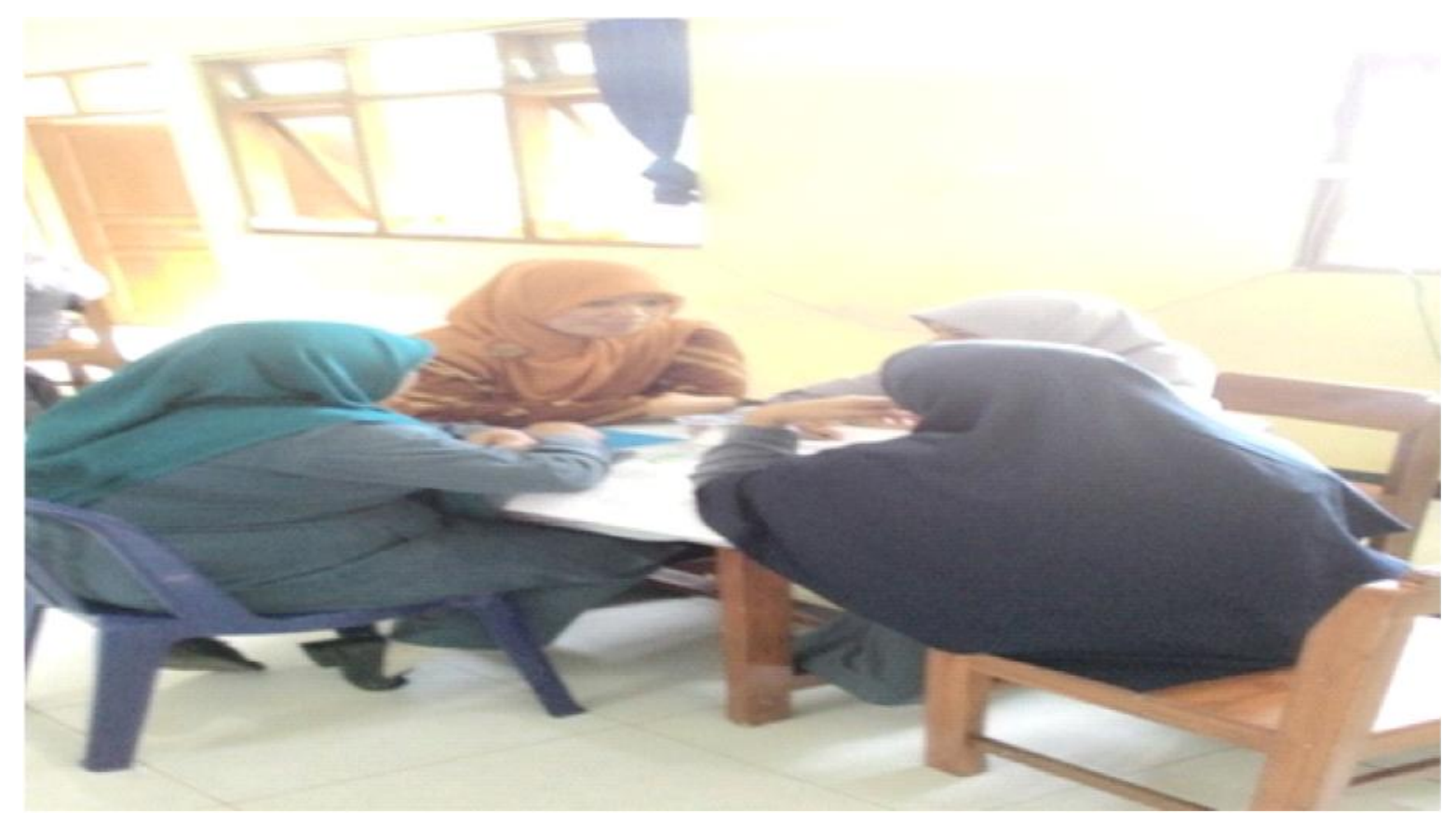

Gambar 4. Kegiatan Diskusi

\section{SIMPULAN}

1. Melihat realitas dalam pelaksanaan kegiatan IbM dalam hal ini adanya antusiasme para peserta mengikuti tahap demi tahap, dari pendalam materi, praktik menulis, dan peer correction, maka kegiatan IbM perlu dilanjutkan. Pentingnya keberlanjutan kegiatan IbM ini juga diperkuat oleh adanya permintaan atau harapan peserta agar kegiatan IbM semacam ini sering dilakukan dan dilanjutkan, khususnya berkaitan dengan strategi mengatasi masalah dalam pelaksanaan pembelajaran atau penyusunan proposal penelitian atau PTK. Alasannya, kegiatan IbM semacam ini merupakan kegiatan yang sangat membantu guruguru dalam meningkatkan kualitas kinerja untuk mengembangkan profesionalitas. Mereka kini termotivasi untuk menuangkan ide dalam bentuk tulisan dan mengembangkan ide tersebut menjadi artikel publikasi ilmiah sebagai salah satu komponen yang harus dipenuhi dalam pengembangan keprofesian berkelanjutan.

2. Pelaksanaan IbM tahap II ini perlu tindak lanjut pada periode berikutnya. Kesulitan guru dalam menentukan metode pembelajaran dan jenis penilaian merupakan alasan yang paling kuat. Guru menyadari bahwa langkah-langkah pembelajaran yang ada di dalam buku guru yang dijadikan sebagai acuan dalam menyusun kegiatan inti dalam RPP perlu didalami secara khusus sehingga kreativitas guru dalam menentukan strategi pembelajaran yang sesuai dapat diciptakan. Begitu juga dengan penilaian, guru mengakui mengalami kendala dalam menentukan teknik penilaian mengingat adanya perubahan paradigma dari penilaian sebelumnya yang cenderung ke arah penilaian kognitif sekarang bergeser ke penilaian afektif dan psikomotorik. Dengan kata lain, penilaian yang sebelumnya dominan berorientasi pada nilai yang berupa angka, sekarang 
penilaian harus didukung dengan penilaian yang berupa verbal.

3. Pelaksanaan IbM tahap III telah mampu memberikan motivasi dan pencerahan guru untuk melakukan identifikasi masalah sehingga judul dan rumusan masalah PTK dapat ditentukan.

\section{PERSANTUNAN}

1. Terima kasih kami ucapkan kepada Dikti yang telah mendanai pelaksanaan kegiatan ini dalam program Ipteks bagi Masyarakat.

2. Teman-teman LPPM yang telah membantu secara administratif pelaksanaan ini.

3. Tim mitra yang telah bekerja sama dengan tim pengabdian dari FKIP UMS

4. Teman sejawat yang senantiasa memotivasi kami untuk terus mengabdi untuk memajukan negeri.

\section{DAFTAR PUSTAKA}

Fakhrudin, Asef Umar. 2009. Menjadi Guru Favorit. Yogyakarta: Diva Press.

Hidayatullah, Furqon. 2010. Guru Sejati: Membangun Insan Berkarakter Kuat dan Cerdas. Surakarta: Yuma Pustaka.

Permenpan. 2009. Jabatan Fungsional Guru dan Angka Kreditnya. Kemenpan \& Reformasi Birokrasi.

Rohmadi, Muhammad. 2012. Menjadi Guru Profesional Berbasis Penilaian Kinerja Guru $(P K G)$ dan Pengembangan Keprofesian Berkelanjutan (PKB). Surakarta: Yuma Pustaka. 